It a $\mathrm{g}$

\title{
DASAR HUKUM EKONOMI ISLAM
}

\begin{abstract}
Abstrak
Ekonomi Islam terbangun dari dasar hukum Naqli dan Aqli. Dalil Naqli adalah dalil yang di ambil dari Al-qur'an atau hadits Nabi Muhammad SAW. Dalil Naqli bisa diartikan juga seperti tanda bukti atau petunjuk dari teks ayat Al-Qur'an, yang tertera dalam mushaf al-Qur'an atau Hadis mutawatir, yang tertera didalam kitab-kitab hadis, lalu diambil dan disalin dari tulisan yang telah baku. Dalil tersebut kebenarannya merupakan kebenaran yang haqiqi/mutlak. Sedang dalil Aqli adalah dalil yang bisa di nalar oleh akal.

Dalil aqli bisa diartikan juga seperti petunjuk dan pertimbangan akal fikiran yang sehat dan obyektif, tidak dipengaruhi oleh keinginan, ambisi atau kebencian dari emosi. Tegasnya dalil aqli adalah penerimaan akal secara murni dan bebas, kebenarannya merupakan nisbi (relatif), karena merupakan prodak manusia. Adapun bentuk dalil aqli berupa Ijtihad: ijma dan qiyas.

Dari dua dasar hukum tersebut, bahwa prinsip prinsip ekonomi Islam tidak boleh menyimpang dari al-Qur'an dan al-Hadits. Sedang dalam pengembangan pemikiran ekonomi Islam tidak lepas dari dasar hukum aqli berupa Ijtihad.
\end{abstract}

Kata Kunci: Hukum, ekonomi, Islam.

\section{Pendahuluan}

Kehidupan sosial ekonomi yang terjadi di masyarakat termasuk umat Islam selama ini telah banyak terjadi pelanggaran dan meninggalkan nilai-nilai atau ajaran agama dalam hal ini Islam. Ajaran-ajaran Islam dalam berekonomi seperti larangan Magrib (Maisir, Gharar dan Riba), menimbun atau mempermainkan penawaran (ikhtikar), mempermainkan permintaan (najasy), menipu (tadlis), taghrir, menjual bukan miliknya ( $b a i$ ' al ma'dum), curang dalam timbangan, eksploitasi sumber daya alam secara serampangan, pemborosan, keserakahan dan sebagainya telah banyak dipraktekan dalam kehidupan ekonomi sehari-harinya dan seolah-olah telah menjadi kebenaran serta keharusan. Pelanggaran syariah dalam berekonomi tersebut telah menyebabkan krisis ekonomi termasuk krisis pada pertengahan 1997 dan financial global pada akhir 2008. Dampak lainnya adalah kerusakan lingkungan, yang kaya makin kaya, kesenjangan ekonomi semakin lebar dan sistem ekonomi yang ada tidak mampu mensejahterakan umat manusia secara keseluruhan melainkan hanya menumpuk pada sebagian masyarakat. ${ }^{1}$

Penyebab krisis tersebut telah nampak sebagaimana dijelaskan dalam alQur'an surat Ar-Rum [30] ayat 41. Sangat jelas pernyataan al-Qur'an tersebut bahwa 
penyebab terjadinya kerusakan yang dalam hal ini krisis adalah akibat ulah manusia itu sendiri. Manusia diberikan amanah oleh Allah SWT. untuk melaksanakan tugasnya di muka bumi ini dengan sebaik-baiknya tidak lepas dari nilai-nilai moral dan segala aturan yang dibuat-Nya, termasuk dalam praktek ekonomi. Islam sebagai agama yang diridloi Allah SWT. untuk manusia mengatur semua aspek kehidupan, baik yang bersifat materil maupun non materil. Karena itu ekonomi sebagai satu aspek kehidupan tentu juga sudah diatur oleh Islam. ${ }^{2}$ Ini bisa dipahami Islam sebagai agama yang sempurna, sebagaimana dinyatakan dalam surat al-Ma'idah [5] ayat 3.

Kesempurnaan Islam sebagaimana ayat di atas dilengkapinya dengan sistem dan konsep ekonomi, suatu sistem yang dapat digunakan sebagai paduan bagi manusia dalam menjalankan kegiatan ekonomi. Suatu sistem yang pada garis besarnya sudah diatur dalam al-Qur'an dan as-Sunnah. Ekonomi Islam sesungguhnya secara inheren merupakan konsekuensi logis dari kesempurnaan Islam itu sendiri. Islam haruslah dipeluk secara kafah dan komprehensif oleh umatnya. Islam menuntut kepada umatnya untuk mewujudkan keislamannya dalam seluruh aspek kehidupannya. Sangatlah tidak masuk akal, seorang muslim yang melaksanakan shalat lima waktu, lalu dalam kesempatan lain ia juga melakukan transaksi keuangan yang menyimpang dari ajaran Islam. ${ }^{3}$ Untuk itulah Ekonomi Islam tidak lepas dari dasar hukum ekonomi Islam, yang akan dibahas dalam tulisan ini.

\section{Dasar Dasar Hukum Ekonomi Islam}

\section{Al-Qur'an}

Al-Qur'an adalah kalam Allah SWT. yang disampaikan kepada Nabi Muhammad SAW. secara mutawatir melalui malaikat Jibril dari mulai surat AlFatihah diakhiri surat An-Nas dan membacanya merupakan ibadah. Al-Qur'an merupakan dasar hukum ekonomi Islam yang abadi dan asli, dan merupakan sumber serta rujukan yang pertama bagi syari'at Islam, karena di dalamnya terdapat kaidahkaidah yang bersifat global beserta rinciannya. ${ }^{4}$ Sebagaimana firman Allah surat anNisa [4] ayat 80:

$$
\text { مَنْ يُطِعِعِ الرَّسُوْلَ فَقََْْ اَطَاعَ اللهُ (النسا: 80) }
$$

Artinya: "Barang siapa mentaati Rasul itu, sesungguhnya ia telah mentaati Allah". 5

Ayat di atas menyatakan bahwa al-Qur'an menjelaskan hukum-hukum syara' itu secara keseluruhan, karena penjelasan-penjelasan as-Sunnah berasal dari alQur'an. Al-Qur'an sebagai sumber pokok bagi semua hukum Islam telah menjelaskan dasar-dasar hukum, seperti memerintahkan kepada manusia agar memenuhi janji (perikatan) dan menegaskan halalnya jual beli beserta haramnya riba. ${ }^{6}$

Banyak ayat menyebutkan berbagai macam kebutuhan hidup manusia, baik yang primer (basic needs) maupun yang sekunder. Seperti kebutuhan pangan, yang diindikasikan dengan menyebutkan pemberian rizki Allah berupa buah-buahan, 
binatang ternak, ikan laut, air susu, kebutuhan pakaian dan perumahan. Semua itu merupakan kebutuhan manusia berupa sandang, pangan dan papan.

Al-Qur'an tidak saja mengatur hubungan antara manusia dengan sesamanya, akan tetapi mengatur pula hubungan antara penciptanya. Al-Qur'an juga bertujuan untuk menciptakan keseimbangan antara hubungan kehidupan spiritual dan material. Dan memerintahkan kepada manusia agar percaya pada hari kebangkitan kembali, hari kiamat dan ganjaran atau hukuman.

Jadi al-Qur'an tidak hanya merincikan tentang pentingnya menyusun dan memelihara hubungan erat dengan Tuhan tetapi juga menjelaskan semua yang mungkin diperlukan untuk memenuhi kehidupan sosial yang lengkap. Al-Qur'an tampil sebagai dokumen yang sejak awal mulanya hingga terakhir berusaha memberi penekanan pada semua ketegangan moral yang perlu bagi perbuatan manusia kreatif. Pusat perhatian al-Qur'an adalah manusia dan perbaikannya. Untuk itu sangatlah penting bagi sesorang untuk bekerja dalam kerangka ketegangan-ketegangan tertentu yang sebenarnya telah terciptakan Tuhan dalam dirinya.

\section{As-Sunnah}

As- Sunnah atau sering disebut juga al-Hadits mempunyai arti yang sama, yaitu segala sesuatu yang disandarkan kepada Nabi Muhammad SAW.baik berupa ucapan, perbuatan maupun takrirnya. Kalaupun ada perbedaan sangat tipis sekali, asSunnah yaitu segala sesuatu yang disandarkan kepada Nabi Muhammad SAW. saja, sedang Al-Hadits disandarkan bukan saja kepada Nabi Muhammad SAW. akan tetapi kepada para sahabat Nabi. As-Sunnah ${ }^{7}$ merupakan sumber hukum yang kedua setelah al-Qur'an, dasar pokok as-Sunnah sebagai sumber hukum, sebagaimana firman Allah surat an-Nisa [4] ayat 59:

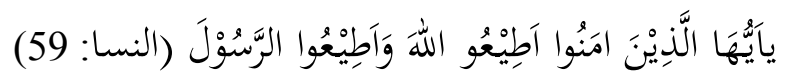

Artinya: "Hai orang-orang yang beriman, taatilah Allah dan taatilah Rasul-Nya". 8

Kedudukan as-Sunnah terhadap al-Qur'an, sebagaimana dirumuskan dalam tiga hal, yaitu: ${ }^{9}$

a. Sunnah berfungsi menjelaskan ayat yang masih mubham, merinci ayat yang mujmal.

b. Sunnah menambah kewajiban-kewajiban syara' yang ketentuan pokoknya telah ditetapkan dengan nash al-Qur'an. Seperti sunnah datang dengan membawa hukum-hukum tambahan yang menyempurnakan ketentuan pokok tersebut.

c. Sunnah membawa hukum yang tidak ada ketentuan nashnya di dalam alQur'an.

Seperti dalam masalah mu'amalat, yaitu al-Qur'an memerintahkan untuk memenuhi janji (perikatan). Hal ini perikatan mana yang sah dan yang halal serta perikatan yang haram dan yang tidak harus dipenuhi, disini as-Sunnah berperan untuk menjelaskannya. 


\section{Ijtihad}

Ijtihad adalah merupakan semua kemampuan dalam segala perbuatan, guna mendapatkan hukum syara' dan dalil terperenci dengan cara istinbat (mengambil kesimpulan). ${ }^{10}$ Dasar hukum ditetapkannya ijtihad sebagaimana firman Allah surat as-Syura' [42] ayat 38:

$$
\text { وَأَمَرهُمْ شُورَىن بَيْنَهُمَ (الشورى: 38) }
$$

Artinya: "Sedang urusan mereka (diputuskan) dengan musyawarat antara mereka"."11

Lapangan ijtihad yaitu masalah-masalah yang belum diatur hukumnya secara pasti oleh al-Qur'an dan as-Sunah. Maka dalam masalah-masalah yang hukumnya sudah diatur secara pasti dan jelas dalam nash al-Qur'an dan as-Sunah tidak perlu lagi berijtihad, melainkan diwajibkan untuk melaksanakan sesuai dengan ketentuan yang telah ditetapkan. ${ }^{12}$

Dalam konsep Islam urusan mu'amalah ini harus berpedoman pada sumbersumber hukum yang telah ditetapkan di atas. Al-Qur'an telah memberikan prinsipprinsip pokok tentang hubungan manusia dengan harta benda sekelilingnya, yaitu dalam tiga hal: ${ }^{13}$

1. Cara mendapatkan hak milik atas harta benda;

2. Penegasan tentang fungsi hak milik, dan

3. Kewajiban membelanjakan harta benda.

\subsection{Cara mendapatkan hak milik atas harta benda harus dengan cara yang halal.}

Islam membolehkan hak pemilikan harta, karena itu merupakan fitrah dalam jiwa mausia. Manusia itu wajib melakukan sesuatu dengan jerih payahnya untuk mendapatkan harta baginya. Jadi kalau hal itu diharamkan maka sama halnya dengan manusia itu mengharamkan masyarakat dari cita-citanya. Maka harta yang didapat itu harus yang halal tidak yang haram. ${ }^{14}$ Sebagaimana firman Allah surat al-Baqarah [2] ayat 188:

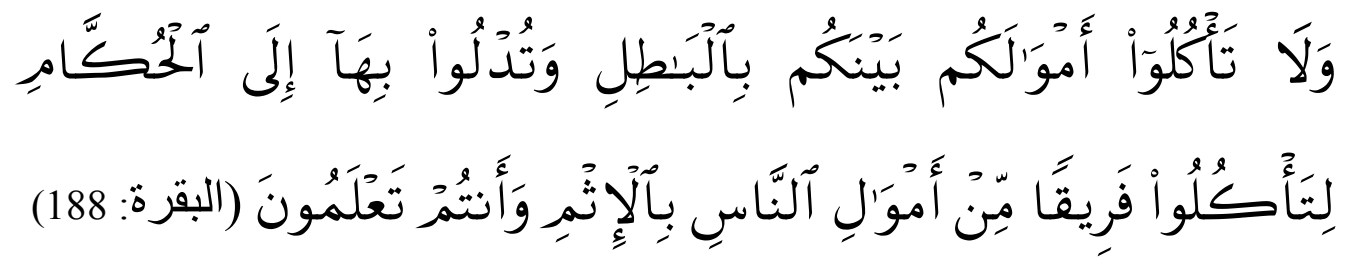

Artinya: "Dan janganlah sebahagian kamu memakan harta sebahagian yang lain di antara kamu dengan jalan yang bathil dan (janganlah) kamu membawa (urusan) harta itu kepada hakim, supaya kamu dapat memakan sebahagian daripada harta benda orang lain itu dengan (jalan berbuat) dosa, padahal kamu Mengetahui". ${ }^{15}$ 


\subsection{Tidak boleh menjalankan riba}

Memperoleh harta benda harus dilakukan dengan cara berusaha dan bekerja. Tidak dibenarkan mendapatkan keuntungan dari riba yakni keuntungan yang diperoleh dari jerih payah orang lain tanpa membayar jerih payah orang itu, dalam si peminjam.

Riba merupakan bencana besar, musibah yang kelam, dan penyakit yang berbahaya. Riba adalah pembunuh dan pemusnah. Orang yang menerima maka kekafiran akan datang kepadanya dengan cepat. Dikepung oleh kemelaratan, berada pada bencana besar, dan kesedihan yang berkepanjangan. Tidak diragukan lagi, kalau seseorang itu pada mulanya berada dalam kemudahan harta benda, kenikmatan jiwa dan kebaikan keadaan kemudian setelah itu menjadi hina diri. Kejerniihan hidupnya menjadi keruh, dan nasibnya menjadi sangat sangat sempit. Dalam keadaan seperti ini, orang yang memakan riba hatinya menjadi goncang, tertipu perasaannya hancur pikirannya seperti orang yang kemasukan syetan. ${ }^{16}$

2.1.Hak (milik) atas harta benda mempunyai nilai sosial

Harta merupakan titipan dari Allah SWT. harus dijaga. Manusia tidak diperbolehkan berlaku serakah, tetapi harus punya kepedulian terhadap sesamanya. Berjiwa sosial, saling tolong-menolong untuk membagi bagi rizki. Guna terciptanya perekonomian yang merata. Sebagaimana firman Allah surat adz-Zariyat [51] ayat 19:

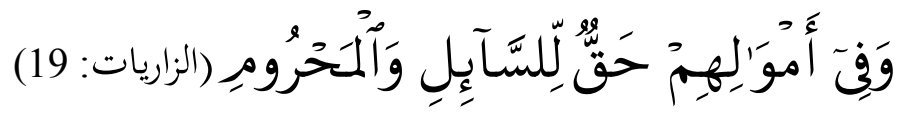

Artinya: "Dan pada harta-harta mereka ada hak untuk orang miskin yang meminta dan orang miskin yang tidak mendapat bagian". ${ }^{17}$

2.2. Tidak boleh menimbun harta kekayaan

Harta kekayaan harus dilepaskan ke dalam peredaran, sehingga menfaatnya dapat diambil menfaatnya oleh banyak orang. Penimbunan barang diancam oleh Allah, sebagaimana firmannya surat at-Taubah [9] ayat 34:

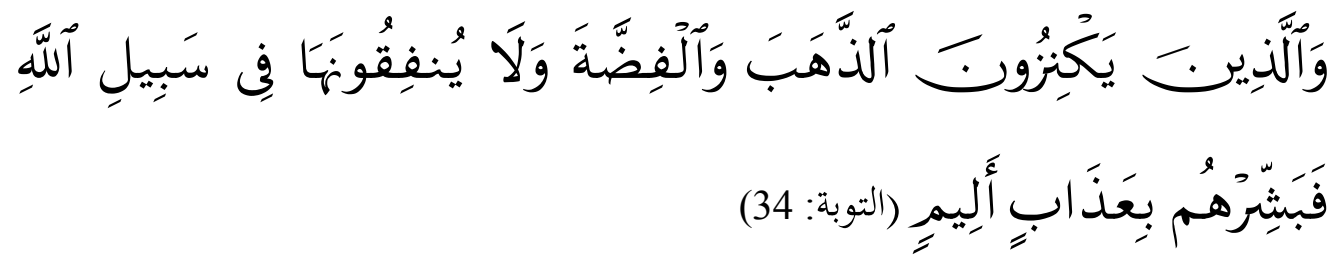

Artinya: "Dan orang-orang yang menyimpan emas dan perak dan tidak menafkahkannya pada jalan Allah, Maka beritahukanlah kepada mereka, (bahwa mereka akan mendapat) siksa yang pedih". 18

3.1.Kewajiban membelanjakan harta benda diatur dengan pedoman sebagai berikut: 
1. Penggunanya

1. Tidak boleh boros dan tidak boleh kikir.

2. Harus hati-hati dan bijaksana dalam menggunakan harta. Seorang yang tidak tahu (bodoh) menggunakan harta benda harus dicegah melakukannya.

2. Mengadakan beberapa lembaga untuk menyalurkan rasa keadilan sosial yang hidup dalam hati manusia untuk kepentingan masyarakat, seperti:

1. Zakat

2. Sedekah dan Hibah

3. Lembaga-lembaga keuangan selain zakat seperti BMI/BMT, Takaful

4. Wakaf

5. Penyembilihan qurban, dan lain-lain

Ijtihad yang diupayakan oleh para ulama menghasilkan kesepakatankesepakatan, di antaranya:

a. Ijma'

Ijma' ialah kebulatan pendapat Fuqoha Mujtahidin pada suatu masa atas sesuatu hukum sesudah masa Rasulallah SAW. ${ }^{19}$ Dan merupakan salah satu dalil syara' yang memiliki tingkat kekuatan argumentatif setingkat di bawah dalil-dalil nash (al-Qur'an dan Hadits). Dasar ditetapkannya ijma sebagai hukum yang ketiga setelah al-Qur'an dan as-sunah, yaitu dalam surat An-Nisa [4] ayat 115:

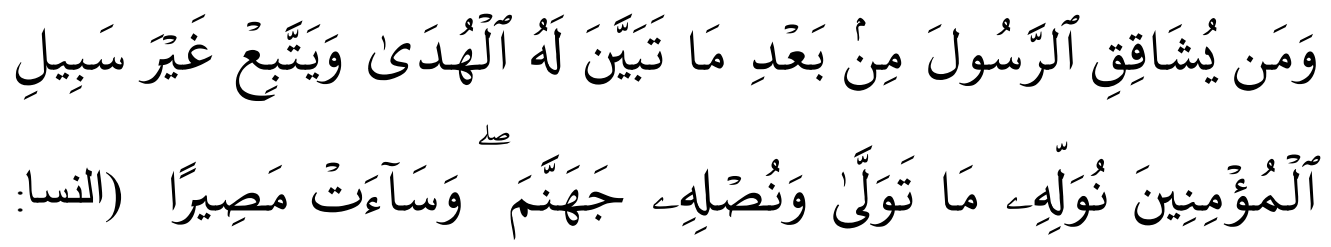

$(115$

Artinya: "Dan barangsiapa yang menentang Rasul sesudah jelas kebenaran baginya, dan mengikuti jalan yang bukan jalan orang-orang mukmin, kami biarkan ia leluasa terhadap kesesatan yang Telah dikuasainya itu dan kami masukkan ia ke dalam Jahannam, dan Jahannam itu seburuk-buruk tempat kembali". ${ }^{20}$

Ijma dibagi dua yaitu ijma qauli dan ijma sukuti. Ijma qauli ialah kebulatan yang dinyatakan oleh mujtahidin dan ijma sukuti ialah kebulatan yang dianggap ada, apabila seseorang mujtahid mengeluarkan pendapatnya dan diketahui oleh mujtahidin lainnya. Akan tetapi mujtahidin lainnya tidak menyatakan setuju atau batalnya.

b. Qiyas

Qiyas adalah mempersamakan hukum sesuatu perkara yang belum ada kedudukan hukumnya dengan sesuatu perkara yang sudah ada ketentuan hukumnya karena adanya segi-segi persamaan antara keduanya yang disebut illat. Qiyas 
merupakan sumber hukum yang keempat setelah al-Qur'an, As-sunnah dan Ijma'. Dasar hukum ditetapkannya qiyas yaitu surat an-Nisa [4] ayat 59:

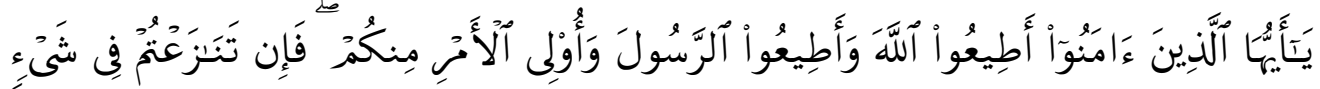

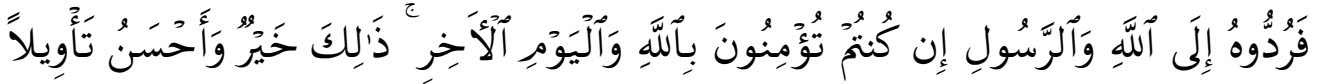

Artinya: "Hai orang-orang yang beriman, taatilah Allah dan taatilah Rasul (nya), dan ulil amri di antara kamu. Kemudian jika kamu berlainan pendapat tentang sesuatu, Maka kembalikanlah ia kepada Allah (Al Quran) dan Rasul (sunnahnya), jika kamu benar-benar beriman kepada Allah dan hari kemudian. yang demikian itu lebih utama (bagimu) dan lebih baik akibatnya". ${ }^{21}$

Dasar hukum teori ekonomi Islam menurut Murasa Sarkaniputra sebagaimana dijelaskan pada tabel di bawah ini:

\section{Dasar Hukum Teori Ekonomi Islam ${ }^{22}$}

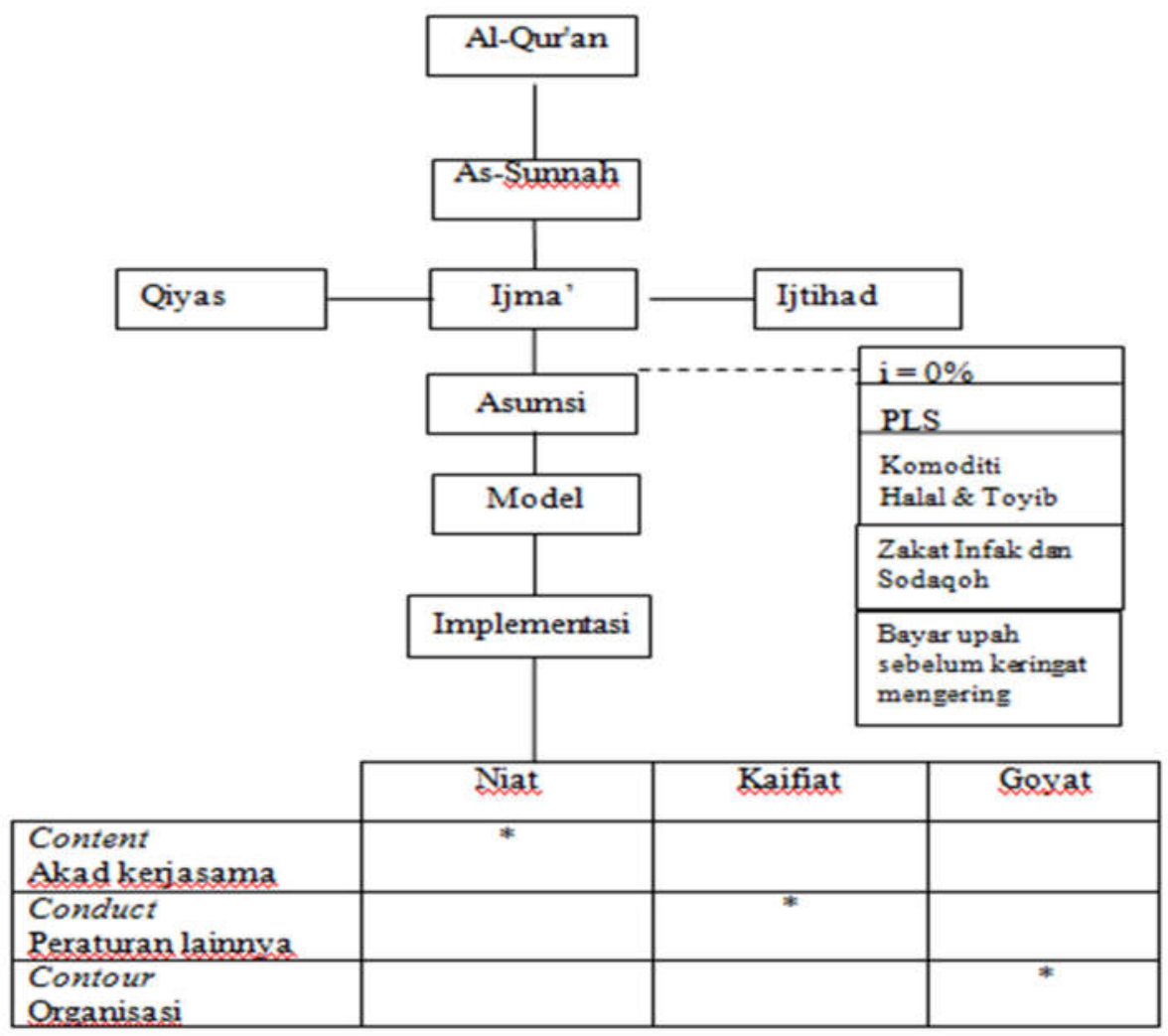


KETERANGAN:

1. Ekonomi Islam bersumber pada al-Qur'an, as-Sunnah, Ijma', Qiyas dan Ijtihad.

2. Asumsi, yaitu sebagai berikut:

c. $\mathrm{i}=0 /$ interest $=0$

Di dalam konsep perekonomian Islam tidak terdapat perbuatan yang mengandung unsur riba, gharar dan judi. Semua hak yang didapatnya dari hasil yang baik sesuai dengan petunjuk qur'ani.

d. Untung dan rugi (profit dan loss sharing/PLS)

Untung dan rugi merupakan resiko yang ditanggung dari kegiatan ekonomi. Neraca keberhasilan usaha tidak mutlak ditentukan manusia, yang menentukan segalanya hanya Allah semata. Oleh karena itu konsep Islam memberikan keseimbangan untuk mengatur rotasi ekonomi dalam masyarakat yaitu dengan adanya untung dan rugi.

e. Halal dan toyib

Perbedaan yang menonjol dibandingkan dengan Prinsip ekonomi lainnya, prinsip Islam yaitu halalal dan toyiban. Agar harta yang dimiliki itu didapat dari komoditi yang halal serta baik. Dari praktek semacam ini akan membentuk etika perekonomian yang baik, yang dapat menciptakan kemakmuran dalam masyarakat.

f. Sebagai wujud keseimbangan antar sesama adalah dengan menunaikan zakat, infaq dan s \{odaqoh.

g. Membayar upah sebelum keringat mengering sebuah tindakan yang mulia.

h. Model berupa BMT, Takaful, Mudharabah, dan lain-lain.

Menurut Sri-Edi Swasono intisari teori ekonomi Islam yang diambil dari dasar hukum ekonomi Islam (Al-Qur'an dan Al-Hadits), yaitu: ${ }^{23} 1$ ). Menekankan moralitas dan etika Islam. Moralitas yang dimaksud dengan pelayanan yang baik, sedangkan etika Islam sesuai dengan prinsip-prinsip Islam. 2). Menghindari praktek kehidupan ekonomi yang tidak Islami. Praktek kegiatan ekonomi dalam kehidupan masyarakat perlu dianalisis dengan merelevansikan dengan prinsip-prinsip Islam. 3). Tidak menafikan ekonomi mainstream. Konsep ekonomi Islam mengembangkan teori ekonomi yang dapat mentransformasi ekonomi mainstream menjadi ekonomi yang Islami. 4). Bebas nilai. Konsep ekonomi Islam mengakui hukum-hukum (bebas nilai) atau tehnik-tehnik ekonomi (bebas nilai) yang dapat dimanfaatkan untuk memperkokoh dan melengkapi kajian-kajian ekonomi Islam. 5). Berasaskan keadilan. Dengan asas keadilan merupakan jalan keluar untuk mengatasi kesulitan-kesulitan ekonomi, pengangguran dan kemiskinan.

Ada beberapa parameter dasar teori ekonomi Islam yang dapat diungkap dan diikhtisarkan sebagai berikut: ${ }^{24} 1$ ). Tindakan dan putusan dinilai etis, tergantung pada maksud (tujuan) individu. Tuhan Maha Mengetahui, karena itu Tuhan mengetahui maksud manusia secara sempurna. 2). Maksud baik yang diikuti tindakan baik dianggap sebagai ibadah (pengabdian). Maksud halal tidak dapat merubah tindakan haram menjadi halal. 3). Islam memberikan kebebasan kepada individu untuk 
meyakini dan bertindak apapun yang diinginkan, namun tanpa mengorbankan keadilan dan tanggung jawab. 4). Iman kepada Allah memberikan individu kebebasan sempurna dari sesuatu atau seseorang kecuali Allah. 5). Keputusan yang menguntungkan mayoritas atau minoritas bukan ukuran etis tidaknya suatu tindakan. Etika bukan persoalan jumlah. 6). Islam menggunakan pendekatan sistem terbuka terhadap etika, tidak tertutup dan berorientasi pada diri sendiri (self-oriented). 7). Keputusan etis didasarkan pada pemahaman terhadap al-Qur'an dan alam semesta secara bersamaan. 8). Berbeda dengan sistem etika yang dibangun oleh kebanyakan agama lain, Islam menganjurkan umat manusia untuk mengamalkan tazkiyah melalui partisipasi aktif dalam kehidupan dunia.

Ekonomi Islam tidak bersifat fragmental (terpenggal-penggal) akan tetapi merupakan bagian yang tak terpisahkan dari pandangan hidup Islami. Karena itu sistem ekonomi Islam bersifat menyeluruh, sebagaimana Firman Allah SWT. surat alBaqoroh (2) ayat 208:

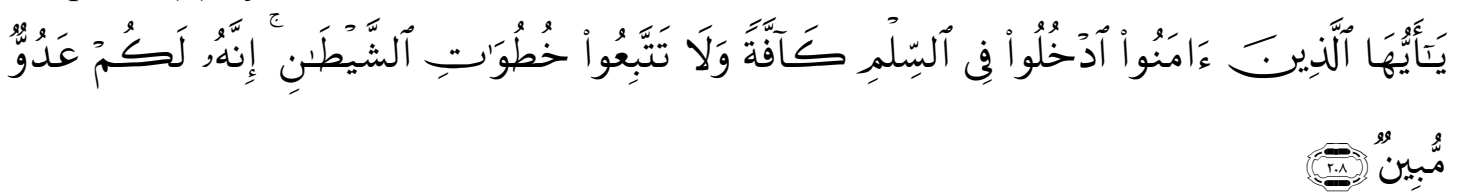

Artinya: Hai orang-orang yang beriman, masuklah kamu ke dalam Islam keseluruhan, dan janganlah kamu turut langkah-langkah syaitan. Sesungguhnya syaitan itu musuh yang nyata bagimu. ${ }^{25}$

Dalam kaidah perilaku individu, terdapat suatu keajegan batini (internal consistency) atau 'adl (=equilibrium). Aksioma equilibrium (keseimbangan) ini merupakan inti dari surat al-Baqarah [2] ayat 143:

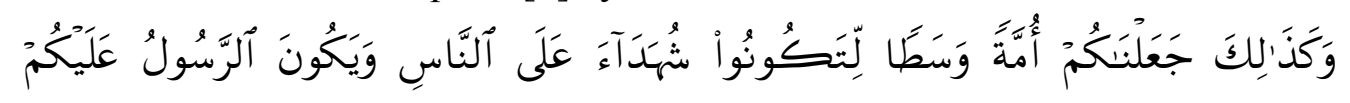

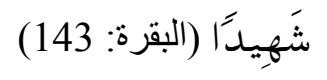

Artinya: "Dan demikian (pula) kami Telah menjadikan kamu (umat Islam), umat yang adil dan pilihan agar kamu menjadi saksi atas (perbuatan) manusia dan agar Rasul (Muhammad) menjadi saksi atas (perbuatan) kamu”. ${ }^{26}$

\section{Kesimpulan}

Dari uraian di atas dalam pembahsan ini dapat disimpulkan bahwa dasar hukum ekonomi Islam terdiri dari: 1. Al-Qur'an 2. Al-Hadits dan 3. Ijtihad (Ijtihad secara jama'i disebut dengan Ijma' sedang Ijtihad secara individu disebut dengan Qiyas). Selanjutnya ada asumsi asumsi dalam prinsip ekonomi Islam, yaitu: Bebas riba, adauntung rugi, komenditi mesti halal dan toyib, membayar zakat infaq dan sodaqoh, hendaknya memeberikan upah sebelum kerngatnya mengering.

Sedangkan model model ekonomi Islam aplikasi dari dasar hukum ekonomi Islam adalah berupa pengembangan institusi/lembaga (perbankan, asuransi, gadai, 
baznas dan lain sebagainya) dan pemikiran pemikiran instrumen berupa gagasan yang terpola dalam bentuk aplikasi ekonomi Islam, seperti; jaminan sosial, upah buruh yang layak, jaminan kesehatan, makanan dan minuman yang halal dan lain lain.

Adapun implementasi dari dasar hukum ekonomi Islam itu adalah berupa niat, aturan dan tujuan. Niat ikhlas karena Allah, aturan berupa undang undang dan regulasi lainnya, sedangkan tujuan adalah ridla Allah untuk beribadah kepadanya.

\section{Catatan Akhir:}

${ }^{1}$ Karjadi Mintaroem, "Kurikulum Ekonomi Syariah di Fakultas Ekonomi Universitas Airlangga dan Perannya dalam Perekonomian Indonesia" Makalah, Disampaikan pada Forum Dekanat PTN seIndonesia, di Fakultas Ekonomi Universitas Padjajaran, tanggal 22-24 Oktober 2009.

${ }^{2}$ Mustafa Edwin Nasution, dkk. Pengenalan Ekslusif Ekonomi Islam (Jakarta: Penerbit Kencana Prenada Media Grouf, cet. ke 3, 2010), 1-2.

${ }^{3}$ Mustafa Edwin Nasution, dkk. Pengenalan Ekslusif Ekonomi Islam (Jakarta: Penerbit Kencana Prenada Media Grouf, cet. ke 3, 2010), 2.

${ }^{4}$ Muhammad Abu Zahrah, Ushul Fiqh, Alih Bahasa Saefullah Ma'sum, dkk., (Jakarta: PT. Pustaka Firdaus, 1994), h. 121

${ }^{5}$ Al-Qur'ān (Jakarta: PT. Tegalyoso Utama, 1974), h. 82.

6 Ahmad Hanafi, Pengantar dan Sejarah Hukum Islam, (Jakarta: Bulan Bintang, 1986), h. 57

${ }^{7}$ dalam konteks hukum Islam, sunanh yang secara harfiah berarti "cara, adat istiadat, kebiasaan hidup" mengacu kepada perilaku Nabi yang dijadikan teladan. (Muhammad Abdul Manan, Op. Cit., h. 32). Sunnah menurut istilah ushul fiqh yaitu segala yang dinukil dari Nabi, baik perkataan maupun perbuatan, ataupun taqrir yang mempunyai hubungan dengan hukum. (Hasbi as-Shiddieqy, Sejarah dan Pengantar Ilmu Hadits, Jakarta: Bulan Bintang, 1991), h. 25.

${ }^{8}$ Al-Qur'ān (Jakarta: PT. Tegalyoso Utama, 1974), h. 79

${ }^{9}$ Muhammad Abu Zahrah, Ushul Fiqh, Alih Bahasa Saefullah Ma'sum, dkk., (Jakarta: PT. Pustaka Firdaus, 1994), h. 161.

${ }^{10}$ Qardhawi, Yusuf, Ijtihad dalam Syari'at Islam, Alih Bahasa Ahmas Syatori, Bulan Bintang, Jakarta, 1987, h. 2.

${ }^{11}$ Al-Qur'ān (Jakarta: PT. Tegalyoso Utama, 1974), h. 144.

${ }^{12}$ Wahab Afif, Tarikh Tasyri' Islam, Serang: CV. Saudara.

${ }^{13}$ Anwar Harjono, Hukum Islam Keluasan dan Keadilannya, (Jakarta: Bulan Bintang, 1987), h. 143.

${ }^{14}$ Mutawali Sya'rawi, Islam di Antara Kapitalisme dan Komunisme, Jakarta: Gema Insani Press, 1993, h. 3.

${ }^{15}$ Al-Qur’ān (Jakarta: PT. Tegalyoso Utama, 1974), h. 27.

${ }^{16}$ Syeikh Ahmad Al-Jurjawi, Falsafah dan Hikmah Hukum Islam. Terjemah Hadi Mulyo, As_Syifa Semarang 1992: 376.

${ }^{17}$ Al-Qur'ān (Jakarta: PT. Tegalyoso Utama, 1974), h. 472.

${ }^{18}$ Al-Qur'ān (Jakarta: PT. Tegalyoso Utama, 1974), h. 174.

${ }^{19}$ Ahmad Hanafi, Pengantar dan Sejarah Hukum Islam, Jakarta: Bulan Bintang, 1986, h. 61.

${ }^{20}$ Al-Qur'ān (Jakarta: PT. Tegalyoso Utama, 1974), h. 79.

${ }^{21}$ Al-Qur'ān (Jakarta: PT. Tegalyoso Utama, 1974), h. 79.

${ }^{22}$ Murasa Sarkaniputra, Revelation-based Measurement; Pendekatan Keterpaduan antara Matik Rasa dan Mantik Akal dari Ibnu Arabi (P3EI UIN Syarif Hidayatullah Jakarta, 2004), 7. 
${ }^{23}$ Pada saat bimbingan pada hari senin tanggal 2 Agustus 2010.

${ }^{24}$ Choirul Fuad Yusuf, Etika Bisnis dalam al-Qur'an (Surabaya: Risalah Gusti, 1999), 14.

${ }^{25}$ Al-Qur'ān (Jakarta: PT Tegalyoso Utama, 1974), 30.

${ }^{26}$ Al-Qur'ān (Jakarta: PT Tegalyoso Utama, 1974), 21.

\section{DAFTAR PUSTAKA}

Al-Qur'ān. Jakarta: PT. Tegalyoso Utama, 1974.

Ahmad Hanafi, Pengantar dan Sejarah Hukum Islam, Jakarta: Bulan Bintang, 1986.

Anwar Harjono, Hukum Islam Keluasan dan Keadilannya, Jakarta: Bulan Bintang, 1987.

Choirul Fuad Yusuf, Etika Bisnis dalam al-Qur'an, Surabaya: Risalah Gusti, 1999.

Karjadi Mintaroem, "Kurikulum Ekonomi Syariah di Fakultas Ekonomi Universitas Airlangga dan Perannya dalam Perekonomian Indonesia" Makalah, Disampaikan pada Forum Dekanat PTN se-Indonesia, di Fakultas Ekonomi Universitas Padjajaran, tanggal 22-24 Oktober 2009.

Muhammad Abu Zahrah, Ushul Figh, Alih Bahasa Saefullah Ma'sum, dkk., Jakarta: PT. Pustaka Firdaus, 1994.

Murasa Sarkaniputra, Revelation-based Measurement; Pendekatan Keterpaduan antara Matik Rasa dan Mantik Akal dari Ibnu Arabi, P3EI UIN Syarif Hidayatullah Jakarta, 2004.

Mutawali Sya'rawi, Islam di Antara Kapitalisme dan Komunisme, (Jakarta: Gema Insani Press, 1993.

Mustafa Edwin Nasution, dkk. Pengenalan Ekslusif Ekonomi Islam. Jakarta: Penerbit Kencana Prenada Media Grouf, cet. ke 3, 2010.

Qardhawi, Yusuf, Ijtihad dalam Syari'at Islam, Alih Bahasa Ahmas Syatori, Bulan Bintang, Jakarta, 1987.

Syeikh Ahmad Al-Jurjawi, Falsafah dan Hikmah Hukum Islam. Terjemah Hadi Mulyo, As_Syifa Semarang 1992.

Wahab Afif, Tarikh Tasyri' Islam, Serang: CV. Saudara. 
Itang, dosen pada Fakultas Syari'ah dan Ekonomi Islam IAIN Sultan Maulana Hasanuddin Banten. 